\title{
HUBUNGAN KEMAMPUAN MEMBACA AL QUR'AN DAN MINAT BELAJAR SISWA DENGAN HASIL BELAJAR PENDIDIKAN AGAMA ISLAM (PAI)
}

\section{THE RELATIONSHIP BETWEEN AL QUR'AN READING ABILITY AND LEARNING INTEREST OF THE STUDENTS WITH THE LEARNING RESULTS OF ISLAM EDUCATION (PAI)}

\author{
Arsyad $^{1}$, Salahudin ${ }^{2}$ \\ ${ }^{1}$ STKIP Muhammadiyah Bogor \\ Jl. Raya Leuwiliang No.106, Leuwiliang, Bogor, Jawa Barat 16640 \\ ${ }^{2}$ Guru DPk Depag pada SMK Tirtayasa Jakarta \\ Jl. Bintaro Raya No.11, Kebayoran Lama, Jakarta Selatan 12240 \\ email: arsyda_2006@yahoo.com \\ email: salahuddinacho@ymail.com
}

Naskah Diterima: 16 Mei 2018; Direvisi: 18 Juli 2018; Disetujui: 28 Agustus 2018

\begin{abstract}
This research aimed to determine the relationship between Al Qur'an reading ability and learning interest of the students, with the learning results of Islam Education (PAI). The problem in this research was the PAI implementation in Senior High School (SMA/SMK) has not been optimally carried out since, $(i)$ in general, the religion lesson is only taught 2 hours per week, in average, (ii) the background of understanding and living Islamic life varies, (iii) the understanding that the PAI lesson does not give direct contribution to the skills demanded in the working world. These problems affected knowledge, attitude, and skill of the PAI results, which are still not optimum. This research used descriptive method. Data collection obtained (1) Al Qur'an reading ability was carried out by conducting Al Qur'an reading test; (2) data of the PAI learning interest of the students was done by delivering questionnaire;(3) data of the PAI results was taken from the school final examination, academic year of 2016/2017. Students with good ability of reading Al Qur'an tend to achieve high result of the PAI lesson, learning interest of the students is significantly related with the student's achievement on the PAI lesson, and there is a positive relationship between the variables in this research, simultaneously, namely the Al Qur'an reading ability and learning interest, with the student's achievement of the PAI lesson.
\end{abstract}

Keywords: Interest in learning; Islamic religious education; Learning outcomes; Reading Al Qur'an; Students

\begin{abstract}
Abstrak
Penelitian ini bertujuan untuk mengetahui hubungan kemampuan membaca Al Qur'an, dan minat belajar siswa dengan hasil belajar Pendidikan Agama Islam (PAI). Masalah dalam penelitian ini adalah bahwa pelaksanaan PAI di Sekolah Menengah Atas (SMA/SMK) belum terlaksana secara optimal, karena secara umum jumlah jam pelajaran agama di sekolah rata-rata dua jam per minggu, latar belakang pemahaman dan kehidupan beragama (Islam) berbeda-beda, ditambah pemahaman bahwa pelajaran PAI tidak berimplikasi secara langsung terhadap skill yang dibutuhkan pada dunia kerja. Masalah tersebut berdampak pada pada pengetahuan, sikap, dan keterampilan hasil PAI yang belum optimal. Metode yang digunakan adalah metode deskriptif. Pengumpulan data dilakukan, yaitu (1) data kemampuan membaca Al Qur'an diambil dengan tes kemampuan membaca Al Qur'an; (2) data minat belajar PAI siswa diambil dengan koesioner; (3) data hasil belajar PAI siswa diambil dari hasil ujian akhir sekolah pada tahun pelajaran 2016/2017. Siswa yang mempunyai kemampuan membaca Al Qur'an dengan baik, mempunyai kecenderungan memperoleh hasil belajar PAI yang tinggi, minat belajar siswa pada PAI berhubungan secara signifikan terhadap prestasi belajar siswa pada PAI, dan ada hubungan positif antara variabel yang ada dalam penelitian
\end{abstract}


ini secara bersama-sama, yaitu kemampuan membaca Al Qur'an dan minat belajar dengan hasil belajar PAI siswa.

Kata kunci: Hasil belajar; Pendidikan Agama Islam; Membaca Al Qur'an; Minat belajar; Siswa

\section{PENDAHULUAN}

Pendidikan agama Islam tingkat Sekolah Menengah Atas (SMA) bertujuan untuk menumbuhkan dan meningkatkan keimanan, melalui pemberian, pemupukan pengetahuan, dan penghayatan, serta pengamalan siswa tentang Islam. Kompetensi dasar mata pelajaran PAI di SMA/SMK berisi sekumpulan kemampuan minimal yang harus dikuasai siswa selama menempuh pendidikan di SMA. Hakikat dalam pembelajaran PAI di sekolah adalah adanya proses transfer nilai, pengetahauan, keterampilan dari generasi ke generasi berikutnya. ${ }^{1}$ Porses pembelajaran pada PAI secara umum mencakup dua hal yaitu; pertama, mendidik siswa untuk berperilaku sesuai dengan nilai-nilai ajaran Islam, kedua mengajak siswa untuk mempelajari dan mendalami ajaran Islam dengan baik. Dalam proses pencapaiannya, prestasi belajar sangat dipengaruhi oleh beberapa faktor, seperti faktor eksternal dan faktor internal. Faktor eksternal di antaranya latar belakang keluarga, sekolah dan masyarakat, sedangkan faktor internal yaitu faktor fisiologis dan psikologis. ${ }^{2}$ Faktor fisiologis merupakan kondisi umum jasmani siswa, dan faktor psikologis merupakan faktor internal yang berpengaruh pada diri siswa dalam proses belajar diantaranya adalah inteleigensi, sikap, bakat, minat dan motivasi.

Berdasarkan survey awal di SMK Titayasa $^{3}$ yang dilakukan bulan februari 2016 tentang hasil belajar PAI pada siswa SMK, menunjukan bahwa rata-rata hasil belajar PAI masih rendah, mulai dari pemahaman yang tercermin dari hasil evaluasi melalui aspek kognitif, afektif, dan psikomotor, menunjukan bahwa perhatian atau minat siswa terhadap pelajaran Pendidikan Agama Islam (PAI) di sekolah, khususnya sekolah-sekolah umum masih rendah di banding dengan perhatian atau

\footnotetext{
${ }^{1}$ Zuhairiani dkk. 1983. Methodik Khusus Pendidikan Agama. Surabaya: Usaha Nasional. hal 43.

${ }^{2}$ Muhibbin Syah. 2001. Psikologi Belajar. Jakarta: Logos Wacana Ilmu. hal 130-132.

${ }^{3}$ SMA Tiryatayasa. 2016. Rapor siswa Tahun Pelajaran 2015/2016. SMK Tirtaya Jakarta.
}

minta siswa terhadap mata pelajaran yang lain, khususnya pada pelajaran yang diujikan secara nasional. Rendahnya perhatian atau minat siswa terhadap pelajaran PAI tersebut berimplikasi pada rendahnya hasil belajar siswa terhadap PAI, hal ini disebabkan beberapa faktor, antara lain faktor siswa itu sendiri dan faktor institusional. Faktor individu siswa disebabkan karena belum munculnya rasa secara psikologi dan kebutuhan terhadap nilai-nilai agama dalam kehidupan siswa. Faktor institusional yaitu; latar belakang sosial ekonomi keluarga siswa, pengaruh teman sebaya, dan faktor media. ${ }^{4}$ Disamping itu,kemampuan membaca Al Qur'an merupakan salah satu faktor yang sangat penting dalam diri siswa yang dapat mempengaruhi hasil belajar siswa pada pelajaran PAI, sebab jika siswa mampu membaca Al Qur'an dengan baik, maka akan muncul dorongan dalam dirinya untuk mendalmi isi kandungan Al Qur'an, hal ini membawa pada pemahaman yang baik terhadap pelajaran PAI. Ini sejalan dengan hasil penelitian Hindatulatifa, bahwa meningkatnya kemampuan siswa dalam pembelajaran al-Quran secara khusus merupakan salah satu aspek penting dalam proses pembelajaran PAI. Hal ini bisa terlihat dari perubahan tingkah laku serta keaktifan siswa dalam mengikuti pembelajaran dan dibuktikan dengan peningkatan prestasi belajar dalam sebuah evaluasi PAI. ${ }^{5}$.

Berdasarkan pendapat ahli dan kajian hasil penelitian, menujukan bawa faktor yang mempengaruhi rendahnya hasil belajar pada PAI siswa adalah faktor internal dan eksternal. Diantara faktor internal antara lain kemapua membaca Al Qur'an dan minat belajar siswa pada PAI. Kemampuan membaca Al Qur'an merupakan salah satu faktor yang sangat penting dalam diri siswa yang dapat

\footnotetext{
${ }^{4}$ W.S. Winkel. 1983. Psikologi Pendidikan dan Evaluasi Belajar. Jakarta: Gramedia. hal 9.

${ }^{5}$ Hindatulatifah. 2017. Peningkatan Minat Dan Prestasi Belajar Al-Qur'an Dengan Metode Dan Bahan Ajar Iqro' Braille Pada Siswa Kelas III SDLB-A Yeketunis Yogyakarta. Jurnal Pendidikan Agama Islam, Vol. XIV, No. 2, Desember.
} 
mempengaruhi hasil belajar siswa pada pelajaran PAI, sebab jika siswa mampu membaca Al Qur'an dengan baik, maka akan muncul dorongan dalam dirinya untuk mendalmi isi kandungan Al Qur'an, hal ini membawa pada pemahaman yang baik terhadap pelajaran PAI. Sementara itu, faktor minat pada siswa mendorong untuk berbuat lebih giat dan lebih baik dalam belajar. Siswa yang berminat mempunyai perhatian, kesenangan, keinginan, sikap, kebiasaan, dukungan, motivasi, pengalaman, dan partisipasi. Selanjutnya minat diekspresikan dalam suatu aktivitas tertentu misalnya siswa yang mempunyai minat terhadap pelajaran PAI, maka ia selalu cenderung untuk memberikan perhatian yang lebih besar terhadap pelajaran tersebut. Minat merupakan suatu dorongan yang menyebabkan terikatnya perhatian individu pada objek tertentu. Minat memiliki sifat pribadi dan pada dasarnya merupakan perhatian yang bersifat khusus. ${ }^{6}$ Minat yang besar terhadap sesuatu merupakan modal dasar untuk mencapai tujuan. Minat belajar yang besar akan menghasilkan prestasi yang tinggi sebaliknya minat belajar yang kurang akan menghasilkan prestasi yang rendah, karena minat sangat besar perannya dalam pembelajaran di sekolah, minat akan berperan sebagai motivating force yakni sebagai kekuatan yang akan mendorong siswa untuk belajar. ${ }^{7}$ Dengan demikian, dapata dipahami bahwa minat siswa terhadap pelajaran PAI adalah kesenangan di dalam diri siswa yang menimbulkan perhatian dan keseriusan dalam mengikuti peroses pembelajaran PAI.

Hubungan kemampuan membaca $\mathrm{Al}$ Qur'an, minat mempelajari PAI dengan hasil belajar siswa pada pelajaran PAI merupakan satu kesatuan dalam pelajaran pendidikan agama Islam yang memiliki tujuan yang sama yaitu mendorong, membimbing dan membina akhlak dan perilaku siswa yang akhirnya mampu memahami isi kandungan Al Qur'an dan haditst sebagai ajaran agama Islam. Sementara minat belajar pada PAI yang dimiliki siswa akan memperlihatkan gejala

\footnotetext{
${ }^{6}$ Yudrik Jahja. 2012. Psikologi Perkembangan. Jakarta: Kencana Prenada Media Group. hal 63.

${ }^{7}$ Dalyono. 1997. Psikologi Pendidikan. Jakarta: Reneka Cipta. hal 25.
}

positif yang diwujudkan pada sikap dan perilaku siswa tehadap proses pembelajaran PAI, sehingga pada akhirnya prestasi belajar PAI menjadi lebih baik. Proses pembelajaran yang kurang kondusif dan rendahnya minat belajar siswa dalam proses pembelajaran akan berpengaruh pada prestasi belajarnya. Hal ini sesuai dengan hasil penelitian Abdul Rohim bahwa, rendahnya minat belajar terlihat jelas di SMP Dwi Putra, meskipun sekolah ini tidak benuansa islami tetapi dalam kurikulumnya terdapat mata pelajaran PAI, kurangnya minat belajar siswa disebabkan kurang efektifnya guru dalam penyampaian materi dan metode yang digunakan tidak berfariasi. ${ }^{8}$ Berdasarkan latar belakang di atas, dapat disimpulkan bahwa kemampuan siswa membaca Al Qur'an mendorong siswa memiliki minat dan keseriusan untuk merngikuti mata pelajari PAI. Dengan demikian siswa yang mempunyai kemampuan membaca Al Qur'an dengan baik memiliki kecenderungan minat belajar terhadap mata pelajaran PAI juga baik. Siswa yang berminat pada mata pelajaran PAI akan serius untuk mengikuti pelajaran PAI, sehingga akan mendapatkan pengetahuan dan pemahaman tentang materi PAI, dan diharapkan dapat mengamalkannya dalam kehidupan sehari-hari, dan inilah yang menjadi tujuan utama dari mata pelajaran PAI di sekolah.

Pokok permasalahan dalam penelitian ini adalah apakah terdapat hubungan kemampuan membaca Al Qur'an, dan minat belajar siswa dengan hasil belajar PAI. Hasil penelitian ini diharapkan dapat dijadikan sebagai acuan dan bahan pertimbangan bagi pihak di sekolah, orang tua dan masyarakat, dalam hal pentingnya kemampuan siswa dalam membaca Al Qur'an disertai dengan minat belajar, dengan tujuan dapat meningkatkan prestasi belajar siswa pada pelajaran PAI. Signifikansi penelitian sebagai hasil yang akan dicapai adalah sebagai berikut; (1) bagi Sekolah, memberikan bahan masukan tentang sejauhmana kemampuan siswa SMK dalam

\footnotetext{
${ }^{8}$ Abdul Rohim. 2011. Pengaruh Minat Belajar Terhadap Prestasi Belajar Siswa Pada Bidang Studi PAI. Skripsi Jurusan Pendidikan Agama Islam Fakultas Ilmu Tarbiyah Dan Keguruan. Skripsi Universitas Islam Negeri Syarif Hidayatullah Jakarta.
} 
membaca Al Qur'an, (2) bagi Sekolah, memberikan bahan masukan tentang sejauhmana minat belajar pada mata pelajaran PAI siswa SMK Tirtayasa Jakarta, (3) bagi akademisi, menambah khasanah keilmuan terutama yang menyangkut minat belajar dan prestasi belajar siswa, khususnya pada mata pelajaran PAI.

\section{Kajian Literatur}

Hubungan kemampuan membaca Al Qur'an dan minat belajar siswa dengan hasil belajar PAI.

Merujuk pada Undang-undang Sistem Pendidkan Nasional Nomor 20 tahun 2003 tentang sistem Pendidikan Pendidikan Nasional bahwa, pendidikan agama dimaksudkan untuk membentuk peserta didik menjadi manusia yang beriman dan bertaqwa kepada tuhan yang maha Esa serta berakhlak mulia. ${ }^{9}$ Tujuan pendidkan Islam yang akan dicapai di sekolah adalah seluruh aspek kemanusiaan meliputi; sikap, tingkah laku, dan penampilan. Zakiyah Drajat mengatakan bahwa, tujuan akhir pendidikan Islam yaitu terbentuknya insan kamil yang bertakwa kepada Allah Swt. ${ }^{10}$ Hal ini juga sejalan dengan pendapat Ahmad D. M. pendidikan Islam adalah bimbingan jasmani dan rohani berdasarkan hukum-hukum agama Islam menuju terbentuknya kepribadian utama menurut ukuran Islam. ${ }^{11}$

Pendidikan agama Islam sebagai usaha untuk membina dan mengembangkan pribadi siswa baik dari segi rohaniah maupun dari segi jasmaniah harus berlangsung secara bertahap. Suatu kematangan yang bertitik akhir pada optimalisasi perkembangan siswa dapat berlangsung bila melalui proses demi proses ke arah tujuan perkembangannya. Untuk itu, hasil PAI di sekolah harus sejalan dengan tujuan pendidikan secara nasional yang dijabarkan dalam kurikulum mata pelajaran PAI di sekolah. Untuk itu, peran semua unsur yang ada di sekolah, seperti guru, orang tua siswa, siswa, dan masyarakat sangat penting dalam

\footnotetext{
${ }^{9}$ Undang-Undang Nomor 20 Tahun 2003, Sistem Pendidikan Nsional. Jakarta: Menkumham. RI. hal. 23.

${ }^{10}$ Zakiyah, el.al. 1993. Ilmu Pendidikan Islam. Jakarta: Bumi Aksara. hal. 30.

${ }^{11}$ Marimba. 1980. Pengantar Filsafat Pedidikan Islam. Bandung: Ma’arif. hal. 19.
}

mendukung keberhasilan pencapaian tujuan Pendidikan Agama Islam di sekolah.

Kemampuan membaca Al Qur'an bagi siswa adalah salah satu hasil aktivitas proses belajar mengajar yang kompleks, dimana diperlukan adanya berbagai faktor yang menunjang keberhasilannya. Indikator kemampuan membaca Al Qur'an dapat diuraikan sebagai berikut: (a) kelancaran membaca Al Qur'an. Lancar ialah tidak tersangkut-sangkut; tidak terputus-putus, tidak tersendat-sendat; fasih; berlangsung dengan baik. (b) Ketepatan membaca Al Qur'an sesuai dengan kaidah tajwid. (c) Kerapihan menulis ayat-ayat Al Qur'an. ${ }^{12}$ Sementara menurut Erlina Farida., bahwa kemampuan membaca Al Qur'an siswa diukur dengan menggunakan 3 indikator kemampuan yaitu bacaan, tajwid, dan makhraj. ${ }^{13}$

Minat secara terminologi adalah sikap jiwa seseorang termasuk ketiga fungsi jiwanya (kognisi, konasi, emosi) yang tertuju pada sesuatu dalam hubungan itu unsur perasan yang terkuat ${ }^{14}$. Perasaan itu biasanya akan menimbulkan minat apalagi bila diperkuat dengan sikap positif, minat akan berkembang lebih baik. ${ }^{15}$ Minat tidak hanya diekspresikan melalui pernyataan yang menunjukkan bahwa siswa lebih menyukai sesuatu daripada yang lainnya, tetapi juga diimplementasikan melalui partisipasi aktif dalam suatu kegiatan. Siswa yang berminat terhadap sesuatu cenderung untuk memberikan perhatian yang lebih besar terhadap sesuatu yang diminati itu dan sama sekali tidak menghiraukan sesuatu yang lain. ${ }^{16}$ Dari pendapat tersebut, dapat disimpulkan bahwa minat belajar dalam penelitian ini adalah kecenderungan jiwa, perhatian siswa terhadap aktivitas belajar PAI, sehingga siswa termotivasi dan tumbuh rasa sukanya terhadap pelajaran PAI.

${ }^{12}$ Dewan Redaksi. 2002. Ensiklopedi Islam. Jakarta: Ichtiar Baru van Hoeve. hal. 43.

${ }^{13}$ Erlina Farida. 2013. Kemampuan Baca Tulis Al Qur'an Dan Penguatan Agama Siswa Madrasah Tsanawiyah di 8 Kota Besar Di Indonesia. Jurnal Edukasi Volume 11, Nomor 3, September-Desember.

${ }^{14}$ Abu Ahmadi. 1991. Psikologi Umum. Jakarta : PT Rineka Cipta. hal. 14.

${ }^{15}$ Winkel. Op.cit. hal. 15.

${ }^{16}$ Syaiful Bahri Djamarah. 1994. Prestasi Belajar dan Kompetensi Guru. Surabaya: Usaha Nasional. Cet. ke-1, hal. 166- 167. 
Sebagai bagian dari proses kajian ilmiah, hasil penelitian yang terdahulu dan relevan juga menjadi rujukan sebagai referensi dari sebuah penelitian yang akan dilaksanakan. Berikut beberapa hasil kajian terdahulu yang relevan dengan penelitian yang dilakukan, yaitu. Pertama; hasil penelitian Puslitbang Lektur Keagamaan Badan Litbang dan Diklat Departemen Agama RI, meneliti kemampuan baca-tulis Al Qur'an pada siswa SMA dan SMK se-Indonesia. Berdasarkan data temuan lapangan menyimpulkan bahwa kemampuan membaca Al Qur'an siswa sebanyak 78,7\% berdasarkan materi tes yang dikerjakannya tergolong sangat baik. $^{17}$ Kedua; Hasil penelitian Dinar Saadah, menjelaskan bahwa, siswa MTsN Model Banda Aceh ada yang berminat membaca Al Qur'an dan juga masih ada yang belum berminat, dimana $73 \%$ itu siswa berminat dalam membaca Al Qur'an sedangkan $27 \%$ siswa masih belum berminat dalam membaca Al Qur'an. ${ }^{18}$ Ketiga; penelitian yang dilakukan oleh Nurhayati menyimpulkan bahwa, gambaran motivasi belajar peserta didik terdapat peserta didik yang memiliki kebutuhan, dorongan dan tujuan untuk tetap antusias dan bersemangat dalam mengikuti proses pembelajaran, namun ada juga peserta didik kurang berminat dan terdorong. Upaya yang dilakukan guru PAI menggunakan teori motivasi ARCS: Attention, dengan cara mengadakan ulangan, menumbuhkan minat, menggunakan metode yang bervariasi dan media pembelajaran. Relevance, guru menunjukkan relevansi materi yang dipelajari dengan kebutuhan peseerta didik. Convidence, guru meningkatkan kepercayaan diri peserta didik. Satisfaction guru menciptakan kepuasan kepada peserta didik dengan pujian verbal dan non verbal, serta pemberian reward. ${ }^{19}$

Dengan memperhatikan hasil penelitian dan pendapat para ahli diatas, maka penelitian yang akan penulis lakukan menjadi penting

\footnotetext{
${ }^{17}$ Maidir Harun. 2007. Kemampuan Baca-tulis Al Qur'an Siswa SMA. Jakarta: Puslitbang Lektur Keagamaan Depag RI. hal. 109.

${ }^{18}$ Dinar Saadah. 2017. Minat Baca Al Qur'an Siswa MTsN Model Banda Aceh. Skripsi. Universitas Islam Negeri Ar-Raniry Darussalam Banda Aceh.

${ }^{19}$ Nurhayati. 2014. Motivasi belajar PAI di SMA Negeri 1 Belawa Kab. Wajo (Perspektif teori. Jurnal Lentera Pendidikan. ARCS). Vol. 17 No. 2 Desember.
}

untuk diwujudkan dan bukan merupakan duplikasi dari penelitian sebelumnya, namun menjadi penelitian verifikasi dengan memperkuat penelitian terdahuu yang relevan. Sisi perbedaan dari penelitian terdahulu adalah penelitian ini mengkaji hasi belajar PAI siswa, hubungannya dengan kemampuan membaca $\mathrm{Al}$ Qur'an dan minat belajar siswa pada PAI, khususnya di sekolah umum.

\section{Kerangka Konseptual}

Dari kajian literatur di atas dapat dipahami bahwa, hasil belajar PAI diperoleh siswa melalui proses pembelajaran di sekolah. Kegiatan pembelajaran PAI di sekolah membutuhkan pendekatan khusus agar siswa mendapatkan hasil belalar yang baik. Diantara faktor untuk meningatkan hasil belajar PAI siswa adalah faktor kemampuan dalam membaca Al Qur'an, karena dengan kemamuan membaca Al Quran dengan baik menjadi motivasi tersendiri pada siswa untuk mempelajari materi PAI. Sementara itu, faktor minat belajar siswa pada pelajaran PAI juga menjadi salah satu faktor yang dapat meningkatkan hasil belajar, karena adanya kesenangan dan keseriusan dalam belajar PAI (Gambar 1).

Pertama. Sebagai input atau masukan dalam pelaksanaan proses pembelajaran PAI adalah siswa. Kedua, proses, siswa mengikuti proses pembelajaran PAI yang dilakasanakan di sekolah, dengan beberapa variabel yang mendukungnya. Diantara variabel yang mendukung dalam proses pembelajaran PAI adalah faktor internal dan ekternal yaitu; kemampuan membaca Al Qur'an dan minat belajar siswa pada PAI. Ketiga, hasil dengan mengacu pada standar kompetensi yang tercantum dalam kurikulum PAI tingat SMA, yaitu pengembangan sikap yang dihasilkan dari proses pembelajaran dengan berkembangnya pengetahuan, keterampilan, dan sikap siswa yang menempatkan pengetahuan sebagai perilaku (behavior), tidak hanya berupa hafalan atau verbal, dalam kehidupan sehari-hari.

\section{Hipotesis Penelitian}


Dari kerangka konseptual di atas, maka hipotesis Nol pada penelitian ini adalah: Pertama, terdapat hubungan kemampuan membaca Al Qur'an dengan hasil belajar pada PAI. Kedua; terdapat hubungan minat belajar pada PAI dengan hasil belajar PAI. Ketiga; terdapat hubungan kemampuan membaca $\mathrm{Al}$ Qur'an dan minat belajar pada PAI dengan hasil belajar PAI. Sementara hipotesis $\mathrm{Ha}$ adalah: Pertama, tidak terdapat hubungan kemampuan membaca Al Qur'an dengan hasil belajar pada PAI. Kedua; tidak terdapat hubungan minat belajar pada PAI dengan hasil belajar PAI. Ketiga; tidak terdapat hubungan kemampuan membaca Al Qur'an dan minat belajar pada PAI dengan hasil belajar PAI.

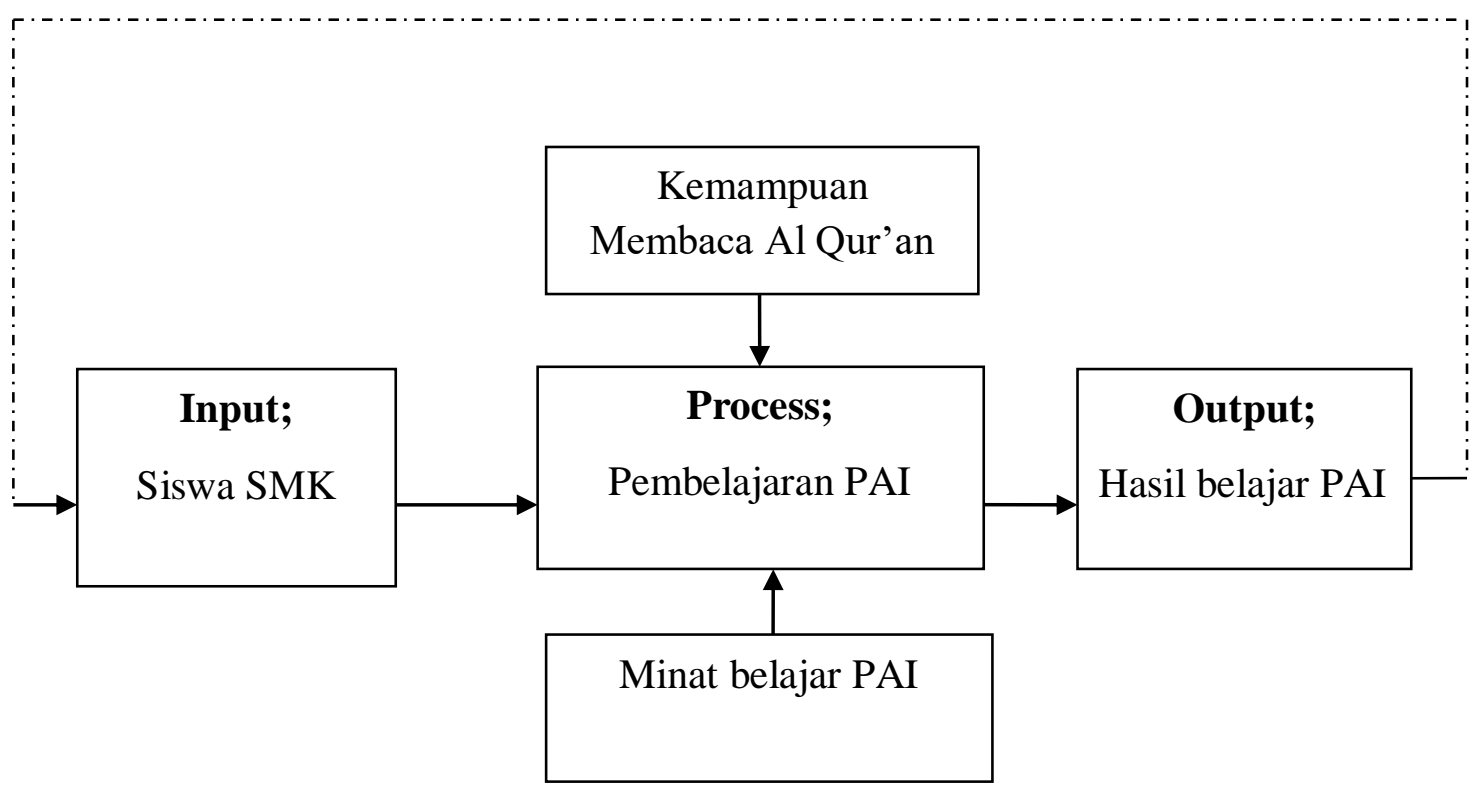

Gambar. 1 Peta permasalahan

\section{METODOLOGI PENELITIAN}

Penelitian di laksanakan di Sekolah Menengah Kejuruan (SMK) Tirtayasa Tanah Kusir Jakarta Selatan pada tahun pelajaran 2016-2017. Metode yang digunakan adalah metode deskriptif yaitu membuat deskriptif secara sistematis, faktual dan akurat mengenai fakat-fakta serta hubungan antar fenomena yang diselidiki, dengan tujuan untuk menguji hipotesis yang menyatakan ada atau tidak hubungan antara variabel bebas (X1) dan (X2) dengan variabel terikat (Y). Populasi dalam penelitian ini adalah seluruh siswa SMK Tirtaya Jakarta kelas X s.d. XII, berjumlah 140 siswa. Sampel penelitian ini berjumlah 40 siswa. Teknik pengambilan sampel yang digunakan adalah teknik random sampling, dengan cara undian. Pengumpulan data dilakukan yaitu; data untuk kemampuan baca Al Qur'an diambil dengan menggunakan tes kemampuan membaca Al Qur'an dengan indikator penilaian, yaitu bacaan, tajwid, dan makhraj. ${ }^{20}$ Data minat belajar PAI siswa

\footnotetext{
${ }^{20}$ Erlina Farida. Jurnal Edukasi. op, cit.
}

diambil dengan menggunakan koesioner yang disampaikan langsung kepada responden, dengan indikator; kebutuhan, rasa senang, ketertarikan, keinginan dan tindaklanjut terhadap apa yang sudah dipelajari dalam pelajaran PAI. Data hasil belajar PAI siswa diambil dari hasil ujian akhir sekolah (UAS) pada tahun pelajaran 2016/2017. Analisis data yang digunakan, pertama; analisis regresi dan korelasi. Analisis regresi yaitu ingin menguji apakah ada atau tidak ada hubungan fungsional antara variabel bebas dan variabel terikat. Sedangkan analisis korelasi ingin mengetahui seberapa besar tingkat keeratan hubungan antar variabel terikat dengan variabel bebas dan agar hasil keputusannya dapat dipertanggung jawabkan, maka koefisien korelasi perlu diuji signifikansinya.

\section{HASIL DAN PEMBAHASAN}

\section{Deskripsi Data}

Pada bagian ini akan disajikan deskripsi data yang diperoleh dari penelitian. Jumlah data sebanyak 40 responden untuk variabel hasil belajar PAI, diperoleh rentang terendah 
skor 60 , dan nilai tertinggi skor 85 , interval 10 ,

modus 85, serta rerata 72,37. Hasil banyak interval 4 , rentang 25 , median 75 dan selengkapnya dapat dilihat pada tabel berikut.

Tabel 1. Distribusi frekuensi hasil belajar PAI

\begin{tabular}{|ccc|c|c|}
\hline \multicolumn{2}{|c|}{ Interval Kelas } & Frekuensi & Frekuensi $(\%)$ relatif \\
\hline 50 & - & 60 & 8 & 20 \\
61 & - & 70 & 12 & 39 \\
71 & - & 80 & 13 & 32,5 \\
81 & - & 90 & 7 & 17,5 \\
\hline \multicolumn{3}{|c|}{$\Sigma$} & 40 & 100 \\
\hline
\end{tabular}

Jumlah data sebanyak 40 responden untuk varibel kemampuan membaca Al Qur'an diperoleh rentang skor 24, interval 10, banyak interval 4, median 80 dan modus 80 serta rerata 67,8. Hasil selengkapnya dapat dilihat pada tabel berikut.

Tabel 2. Distribusi frekuensi kemampuan membaca Al Qur'an

\begin{tabular}{|c|c|c|}
\hline Interval Kelas & Frekuensi & Frekuensi $(\%)$ relatif \\
\hline $50-60$ & 8 & 20 \\
$61-70$ & 12 & 30 \\
$71-80$ & 14 & 35 \\
$81-90$ & 9 & 22,5 \\
\hline$\Sigma$ & 40 & 100 \\
\hline
\end{tabular}

Berdasarkan data minat belajar PAI, dengan nilai terendah 65 tertinggi 90. Secara keseluruhan skor yang diperoleh dari hasil minat belajar PAI diperoleh interval 5, banyak interval 6, median 80 modus 75 , dan rerata 76,75. Hasil selengkapnya dapat dilihat pada tabel berikut.

Tabel 3. Distribusi frekuensi minat belajar PAI

\begin{tabular}{|ccc|c|c|}
\hline \multicolumn{2}{|c|}{ Interval Kelas } & Frekuensi & Frekuensi $(\%)$ relatif \\
\hline 60 & - & 65 & 8 & 20 \\
66 & - & 70 & 0 & 0 \\
71 & - & 75 & 14 & 35 \\
76 & - & 80 & 9 & 22,5 \\
81 & - & 85 & 6 & 15 \\
86 & - & 90 & 3 & 7,5 \\
\hline \multicolumn{2}{|c|}{} & $\Sigma$ & 40 & 100 \\
\hline
\end{tabular}

\section{Analisis Hasil Penelitian}

Analisis penelitian untuk membuktikan hipotesis, pertama analisis persamaan regresi, kemudian dilakukan analisis uji linieritas dan analisis korelasional. Hasil pengujian pengaruh disajikan dalam tabel berikut.

Tabel 4. Rangkuman persamaan regresi

\begin{tabular}{|c|c|}
\hline Regresi & Persamaan Regresi \\
\hline Y atas X1 & $\tilde{Y}=187,46+0,44 X 1$ \\
Y atas X2 & $\tilde{Y}=47,96+1,16 \mathrm{X} 2$ \\
Y atas X1 dan X2 & $\tilde{Y}=15,7+0,17 X 1+1,71 \mathrm{X} 2$ \\
\hline
\end{tabular}


Tabel 5. Hasil uji linearitas dan keberartian regresi

\begin{tabular}{|c|c|c|c|}
\hline Linearitas & F-hitung & F-tabel & Kesimpulan Linearitas \\
\hline $\begin{array}{c}\mathrm{a} 1 \mathrm{Xb} 1 \mathrm{X} 1 \\
\mathrm{aXbX} 2 \\
\end{array}$ & $\begin{array}{l}0,23 \\
0,06 \\
\end{array}$ & $\begin{array}{l}3,23 \\
4,54 \\
\end{array}$ & $\begin{array}{l}\text { Fh }<\text { Ft Regresi linear } \\
\text { Fh }<\text { Ft Regresi linear }\end{array}$ \\
\hline Linearitas & F-hitung & F-tabel & Kesimpulan Linearitas \\
\hline $\begin{array}{c}\mathrm{Y} \text { atas } \mathrm{X} 1 \\
\mathrm{Y} \text { atas } \mathrm{X} 2 \\
\mathrm{Y} \text { atas } \mathrm{X} 1 \text { dan } \mathrm{X} 2 \\
\end{array}$ & $\begin{array}{l}5,00 \\
6,00 \\
5,23\end{array}$ & $\begin{array}{l}(1 / 38 ; 0,05) 4,10 \\
(1 / 38 ; 0,05) 4,10 \\
(2 / 37 ; 0,03) 3,25\end{array}$ & $\begin{array}{l}\text { Fh }>\text { Ft Regresi Signifikan } \\
\text { Fh }>\text { Ft Regresi Signifikan } \\
\text { Fh }>\text { Ft Regresi Signifikan }\end{array}$ \\
\hline
\end{tabular}

Dari hasil regresi disajikan pada tabel 4 dan 5 di atas dapat diartikan bahwa terbukti teruji ada hubungan fungsional antara variabel $\mathrm{X} 1$ dengan $\mathrm{Y}$, karena persamaan regresi $\tilde{\mathrm{Y}}=$ 187,46+0,44X1, berdasarkan hasil uji linearitas regresi persamaan dimaksud linier dan berdasarkan hasil uji regresi persamaan dimaksud signifikan. Terbukti teruji ada hubungan fungsional antara variabel $\mathrm{X} 2$ dengan $\mathrm{Y}$, karena persamaan regresi $\tilde{Y}=$ 47,96+1,16X2, berdasarkan hasil uji linearitas regresi persamaan dimaksud linier dan berdasarkan hasil uji regresi persamaan dimaksud signifikan. Terbukti teruji ada hubungan fungsional antara variabel $\mathrm{X} 1$ dan $\mathrm{X} 2$ dengan $\mathrm{Y}$, karena persamaan regresi $\tilde{\mathrm{Y}}=$ $15,7+0,17 \mathrm{X} 1+1,71 \mathrm{X} 2$ berdasarkan hasil uji linearitas regresi persamaan dimaksud linier dan berdasarkan hasil uji regresi persamaan dimaksud juga signifikan.

Rangkuman hasil perhitungan koefisien korelasi dan hasil uji signifikan koefisien korelasi sebagai berikut.

Tabel 6. Hasil perhitungan koefisien korelasi

\begin{tabular}{|c|c|}
\hline Korelasi & Koefisien korelasi \\
\hline ry1 & 0,26 \\
ry2 & 0,88 \\
Ry.12 & 0,87 \\
\hline
\end{tabular}

Tabel 7. Hasil uji signifikan koefisien korelasi

\begin{tabular}{|c|c|c|c|}
\hline Korelasi & T-hitung & T-tabel & Kesimpulan koefisien korelasi \\
\hline ry1 & 12,83 & 1,67 & T-hit >table, koef korelasi signifikan \\
ry2 & 14,28 & 1,67 & T-hit $>$ table, koef korelasi signifikan \\
Ry.12 & 13,41 & 1,67 & T-hit $>$ tabel, koef korelasi signifikan \\
\hline
\end{tabular}

Dari hasil perhitungan analisis korelasi seperti disajikan pada tabel $7 \mathrm{di}$ atas dapat diartikan: Pertama, terdapat pengaruh positif yang signifikan antara variabel $\mathrm{X}_{1}$ dengan variabel $\mathrm{Y}$, dengan adanya korelasi $\mathrm{r} \mathrm{y}_{1}=$ 12,83 dengan hasil uji koefisien korelasi yang signifikan pada $\alpha=5 \%$ serta diperjelas bahwa $70 \%$ variasi $\mathrm{Y}$ dipengaruhi oleh $\mathrm{X}_{1}$. Kedua, terdapat pengaruh positif yang signifikan antara variabel $\mathrm{X}_{2}$ dengan variabel $\mathrm{Y}$, dengan adanya korelasi $\mathrm{r} \mathrm{y}_{2}=14,28$ dengan hasil uji koefisien korelasi yang signifikan pada $\alpha=5$ $\%$ serta diperjelas bahwa $80 \%$ variasi $\mathrm{Y}$ dipengaruhi oleh $\mathrm{X}_{2}$. Ketiga, terdapat pengaruh positif yang signifikan antara variabel $\mathrm{X}_{1}$ dan
$\mathrm{X}_{2}$ dengan variabel $\mathrm{Y}$, dipertegas adanya korelasi $\mathrm{Ry}_{\cdot 12}=13,41$ dengan hasil uji koefisien korelasi yang signifikan pada $\alpha=5$ $\%$ serta diperjelas bahwa $70 \%$ variasi $\mathrm{Y}$ dipengaruhi oleh $\mathrm{X}_{1}$ dan $\mathrm{X}_{2}$.

Berdasarkan uraian hasil perhiutngan analisis regresi dan korelasi dapat diartikan bahwa hasil penelitian ini adalah: Pertama, terdapat hubungan positif antara variabel kemampuan membaca Al Qur'an $\left(\mathrm{X}_{1}\right)$ dengan hasil belajar PAI (Y). Kedua, Terdapat hubungan positif antara variabel minat belajar PAI $\left(\mathrm{X}_{2}\right)$ dengan hasil belajar PAI (Y). Ketiga, Terdapat hubungan positif antara variabel kemampuan membaca Al Qur'an $\left(\mathrm{X}_{1}\right)$ dan 
minat belajar PAI $\left(\mathrm{X}_{2}\right)$ dengan hasil belajar PAI (Y).

\section{Interpretasi Hasil Penelitian}

Berdasarkan hasil uji regresi dan korelasi, maka penelitian ini dapat diartikan bahwa: Pertama, kemampuan membaca $\mathrm{Al}$ Qur'an mempunyai hubungan positif dengan hasil belajar PAI, dengan demikian hipotesis yang diajukan terdapat hubungan positif antara kemampuan membaca Al Qur'an dengan hasil belajar PAI siswa dapat diterima. Kedua, minat belajar pada PAI mempunyai hubungan positif dengan hasil belajar PAI siswa, dengan demikian hipotesis yang diajukan terdapat hubungan positif antara minat belajar pada PAI dengan hasil belajar PAI siswa dapat diterima. Ketiga, kemampuan membaca Al Qur'an dan minat belajar PAI mempunyai pengaruh positif dengan hasil belajar PAI siswa, dengan demikian hipotesis yang diajukan terdapat hubungan positif antara kemampuan membaca Al Qur'an dan minat belajar PAI dengan hasil belajar PAI siswa dapat diterima.

Zuhairini menjelaskan bahwa pendidikan Agama Islam berarti usaha-usaha secara sistematis dan pragmatis dalam membantu anak didik supaya hidup sesuai dengan ajaran Islam. $^{21}$ Untuk mencapai hasil tersebut, maka peran semua unsur sekolah, orang tua siswa dan masyarakat sangat penting dalam mendukung keberhasilan pencapaian tujuan PAI.

Hasil belajar setiap siswa di kelas terkumpul dalam himpunan hasil belajar kelas. Bahan mentah hasil belajar terwujud dalam lembar-lembar jawab soal ulangan atau ujian, dan yang berwujud karya atau benda. Semua hasil belajar tersebut merupakan bahan yang berharga bagi guru dan siswa. Bagi guru, hasil belajar siswa di kelasnya berguna untuk melakukan perbaikan tindak mengajar dan evaluasi. Bagi siswa, hasil belajar tersebut berguna untuk. Dalam usaha pencapaian tujuan belajar perlu diciptakan adanya sistem lingkungan (kondisi) belajar yang lebih kondusif. Oleh karena itu tujuan belajar meliputi; mendapat pengetahuan, penanaman konsep dan keterampilan, pembentukan sikap.

${ }^{21}$ Zuhairini. 1983. Metodik Khusus Pendidikan Agama Islam. Jakarta: Usaha Nasional. hal. 27.
Hal ini selaras dengan Kurikulum 2013 yang dirancang untuk mengembangkan kompetensi yang utuh antara pengetahuan, keterampilan, dan sikap. Peserta didik tidak hanya diharapkan bertambah pengetahuan dan wawasannya, tetapi juga meningkat kecakapan dan keterampilannya serta semakin mulia karakter dan kepribadiannya. ${ }^{22}$

Dimyati dan Mudjiono, menjelaskan bahwa ada dua faktor yang mempengaruhi hasil belajar yaitu: faktor intern dan faktor ekstern. Faktor intern, antara lain; motivasi belajar, rasa percaya diri siswa, dan cita-cita siswa. Sementara faktor ekstern, yaitu; keluarga, sekolah, dan masyarakat. ${ }^{23}$ Dengan demikian dapat dipahami bahwa untuk mendapatkan hasil belajar yang maksimal tidak terlepas dari dua faktor utama, yaitu faktor internal antara lain motivasi atau minat siswa dalam belajar, dan faktor eksternal sekolah melalui program guru dan keluarga melalui bimbingan orang tua.

Faktor pengetahuan dasar yang dilimiki, yaitu kemampuan membaca Al Qur'an pada siswa memiliki pengaruh yang mendorong siswa untuk meningkatkan pengetahuan agamanya. Hal ini sesuai dengan konsep bahwa ajaran Islam bersumber dari agama Islam adalah yang tertera dalam Al Quran maupun hadits Nabi, sehingga langkah pertama dan utama untuk mempelajari agama Islam adalah memiliki kemampuan membaca Al Qur'an. Mempelajari Al Qur'an itu sebenarnya tidak terlalu sulit, asal ada kemauan dan usaha dalam mempelajarinya pasti akan mampu membaca dan memahami Al Qur'an dengan baik, Allah sudah menjamin kemudahannya bagi umat yang mau mempelajari Al Qur'an, firman Allah dalam Al Qur'an, yang artinya: "Dan sesungguhnya telah kami mudahkan Al Qur'an untuk pelajaran maka adakah orang yang mau mengambil pelajaran." (QS. al-Qomar: 17). Dari ayat tersebut, dapat dipahami bahwa, mempelajari Al Qur'an tidaklah terlalu sulit asal ada kemauan yang keras untuk mempelajari dan memahaminya sedikit demi

\footnotetext{
${ }^{22}$ Kementerian Pendidikan dan Kebudayaan. 2014. Pendidikan Agama Islam dan Budi Pekerti. Jakarta: Pusat Kurikulum dan Perbukuan, Balitbang, Kemdikbud.

${ }^{23}$ Dimyati dan Mudjiono. Op. cit. hal. 77.
} 
sedikit, maka akhirnya nanti akan memperoleh kemampuan membaca Al Qur'andengan baik, karena Allah menurunkan Al Qur'an sedikit demi sedikit, dengan tujuan agar mudah dipelajari, dipahami dan diamalkan, bukan untuk mempersukar hidup manusia. ${ }^{24}$

Faktor minat belajar juga memberikan kontribusi yang signifikan terhadap peningkatan hasil belajar PAI siswa. Faktor yang mendasari pencapaian tujuan PAI adalah faktor internal, yaitu memiliki keinginan yang kuta, dengan minat yang kuat mendorong siswa untuk mendalami materi pelajaran lebih serius. Belajar merupakan cara seseorang untuk mendapatkan berprestasi, agar mampu melakukan sesuatu. Ahmadi, memberikan penjelasan lebih luas dengan mengatakan bahwa minat berarti kecenderungan seseorang untuk memilih atau menolak suatu keinginan, sebenarnya yang dicari bukan kegiatan saja tetapi orang, benda maupun situasi dengan pengertian yang lebih luas. ${ }^{25}$ Unsur yang dan menjadi perhatian siswa di sekolah dapat berupa bahan pelajaran, situasi kelas dan lingkungan bahkan gurunya, jika siswa tertarik dan punya minat atau perhatian terhadap sesuatu maka seluruh daya jiwa akan dicurahkan pada apa yang diperhatikan. Karena minat yang besar terhadap sesuatu merupakan modal dasar untuk mencapai tujuan. Oleh karena itu minat belajar yang besar akan menghasilkan prestasi yang tinggi sebaliknya minat belajar yang kurang akan menghasilkan prestasi yang rendah. Ketika siswa mempunyai semangat, motivasi dan minat yang tinggi untuk belajar pada mata pelajaran, maka akan mudah untuk memhamai materinya, akan tetapi jika tidak memiliki minat dan motivasi tersebut maka tentu akan malas untuk mempelajarinya sehingga berpengaruh pada pencapaian prestasi yang akan dicapai.

Berdasarkan uraian di atas, dapat disimpulkan bahwa untuk mendapatkan hasil belajar yang baik, maka harus memperhatikan faktor intern dan faktor ekstern. Pembelajaran PAI di sekolah, dengan materi pokok adalah Al Qur'an dan Hadist, sebagai motivasi awal agar siswa tertarik untuk mempelajari PAI. Dengan

\footnotetext{
${ }^{24}$ Departemen Agama RI. 1998. Al Qur'an dan Terjemahnya. Jakarta: PT Intermasa.

${ }^{25}$ Abu Ahmadi. Op.cit., hal. 54.
}

demikian, maka kemampuan untuk membaca Al Qur'an sebagai motivasi awal menjadi hal penting untuk mencapai hasil belajar PAI yang baik, karena Al Qur'an sebagai sumber bacaan utama dalam mempelajari PAI. Di samping itu, agar hasil belajar juga maksimal, maka faktor intern juga harus menjadi bagian penting dalam proses pembelajaran siswa di sekolah, dalam hal ini faktor guru dan orang tua siswa. Keterlibatan guru dan orang tua dalam memberikan bimbingan dan dorongan untuk belajar akan memebrikan dampak positif terhadap keseriusan siswa dalam mengikuti proses pembelajaran di sekolah.

\section{UCAPAN TERIMA KASIH}

Hasil penelitian ini tidak terlepas dari bantuan semua pihak yang telah memberikan data dan informasi, penulis sampaikan terima kasih ditujukan kepada kepala sekolah, para guru, dan siswa/i Sekolah Menengah Kejuruan (SMK) Tirtayasa Tanah Kusir Jakarta Selatan. Terima kasih juga penulis sampaikan kepada redaksi Jurnal Edukasi yang berkenan memuat tulisan ini.

\section{PENUTUP}

Dari hasil atas penelitian dan pembahasan di atas dapat simpulkan: Pertama, bahwa siswa yang mempunyai kemampuan membaca Al Qur'an dengan baik, mempunyai kecenderungan untuk memperoleh hasil belajar PAI yang tinggi. Kesimpuan tersebut sesuai dengan landasan teori telah dikemukakan diatas, bahwa kemampuan membaca Al Qur'an menjadi dasar utama untuk mempelajari agama Islam. Kedua, bahwa minat belajar siswa pada PAI berhubungan secara signifikan terhadap prestasi belajar siswa pada PAI. Kesimpuan tersebut sesuai dengan landasan teori telah dikemukakan diatas, bahwa minat belajar yang tinggi pada siswa, mendorong siswa untuk memahami pelajaran, sehingga mendapatkan hasil belajar PAI yang tinggi. Ketiga, bahwa hasil penelitian ini membuktikan adanya hubungan positif antara variabel yang ada dalam penelitian ini, yaitu kemampuan membaca Al Qur'an dan minat belajar dengan hasil belajar PAI siswa mempuyai hubungan yang positif.

Penelitian ini dapat terlaksana dengan baik, berkat dukungan dan bantuan dari 
beberapa pihak yang terkait. Oleh karena itu, kami ucapkan terima kasih atas kerjasama dan dukungan yang diberikan selama penelitian berlangsung. Pertama; kami ucapkan banyak terima kasih kepada kepala Sekolah Kejuruan (SMK) Tirtayasa Jakarta, yang telah memberikan izin untuk melaksanakan penelitian. Kedua; wakil kepala Sekolah SMK bidang kesiswaan dan kurikulum yang telah memfasilitasui untuk pengambilan data pada siswa. Ketiga; Kepada bapak/ibu guru SMK Tirtayasa Jakarta, dan bapak/ibu dosen STKIP Muhammadiyah Bogor yang telah memberikan masukan dan saran selama kegiatan penelitian berlangsung. Untuk itu, kami berdoa kepada Allah Swt. semoga kerjasama dan dukungan dari semua pihak mendapatkan balasan berupa pahala dari-Nya, dan dijadikan sebagai amal shaleh dalam pengembangan ilmu pengetahuan demi kemajuan Pendidikan Agama Islam.

\section{DAFTAR PUSTAKA}

Ahmadi, Abu. (1991). Psikologi Umum. Jakarta; Rineka Cipta.

Abd. Rouf. 2015. Potret Pendidikan Agama Islam di Sekolah Umum. Jurnal Pendidikan Agama Islam Volume 03, Nomor 01, Mei, hal 197-206.

Dinar Saadah. (2017). Minat Baca Al Qur'an Siswa MTsN Mode. Skripsi Universitas Islam Negeri Ar-Raniry Darussalam Banda Aceh.

Departemen Agama RI.(1998). Al Qur'an dan Terjemahnya. Jakarta: PT Intermasa.

Drajat, Zakiyah, el.al. (1993). Ilmu Pendidikan Islam. Jakarta: Bumi Aksara.

D. Ahmad, Marimba, (1980). Pengantar Filsafat Pedidikan Islam. Bandung: Ma'arif.

Dimyati dan Mudjiono, (1999). Belajar dan Pembelajaran. Jakarta: Rineka Cipta.

Dalyono, M., (1997). Psikologi Pendidikan. Jakarta: Rineka Cipta.

Dewan Redaksi Ensiklopedi Islam. (2002). Ensiklopedi Islam. Jakarta: Ichtiar Baru van Hoeve.

Erlina Farida. (2013). Kemampuan Baca-Tulis Al Qur'an dan Penguatan Agama Siswa Madrasah Tsanawiyah di 8 Kota Besar di Indonesia. Jurnal Edukasi. Volume 11, Nomor 3, September-Desember.
Hindatulatifah. (2017). Peningkatan Minat Dan Prestasi Belajar Al- Qur'an Dengan Metode Dan Bahan Ajar Iqro' Braille Pada Siswa Kelas III SDLB-A Yeketunis Yogyakarta. Jurnal Pendidikan Agama Islam. Vol. XIV, No. 2, Desember.

Hayadin, (2011). Implementasi Kebijakan Pemerintah Daerah tentang Kemampuan Baca Tulis Al Qur'an. Jurnal Edukasi. Volume 9. No.1, Januari-April.

Isma'il. (20009). Implementasi Pendidikan Agama Islam Di Sekolah Menengah Umum (SMU) (Problematika dan Pemecahannya). Jurnal FORUM TARBIYAH. Vol. 7, No. 1, Juni.

Jahja, Yudrik. (2012). Psikologi Perkembangan. Jakarta: Kencana Prenada Media Group.

Kementerian Pendidikan dan Kebudayaan. (2014). Pendidikan Agama Islam dan Budi Pekerti/Kementerian Pendidikan dan Kebudayaan. Jakarta: Pusat Kurikulum dan Perbukuan, Balitbang, Kemdikbud.

Ludjito, Ahmad. (1998). Pendidikan Agama Sebagai Subsistem danImplementasinya Dalam Pendidikan Nasional, dalam buku Chabib Thoha dan Abdul Mu'ti (penyunting), PBM-PAI di Sekolah (Eksistensidan Proses Belajar Mengajar Pendidikan Agama Islam), Yogyakarta: Pustaka Pelajar bekerjasama dengan Fakultas Tarbiyah IAIN Walisongo Semarang.

Mutammimal Husna. (2005). Hubungan Kemampuan Membaca Al Qur'an Dengan Prestasi Pendidikan Agama Islam Peserta Didik Kelas VII SMP Negeri 2 Sungguminasa Kabupaten Gowa. Tesis Pada Pascasarjana Universitas Islam Negeri Alauddin Makassar.

Maidir Harun. (20007). Kemampuan Bacatulis Al Qur'an Siswa SMA. Jakarta: Puslitbang Lektur Keagamaan Depag RI.

Nurhayati. (2014). Motivasi belajar PAI di SMA Negeri 1 Belawa Kab. Wajo (Perspektif teori ARCS). Jurnal Lentera Pendidikan. Vol. 17 No. 2 Desember.

SMK Tirtaya Jakarta. (2015). Rapor Siswa Tahun Pelajaran 2015/2016. Jakarta: SMKTirtaya. 
Syaiful Bahri Djamarah, (1994). Prestasi Belajar dan Kompetensi Guru. Surabaya: Usaha Nasional.

Undang-Undang Nomor 20 Tahun 2003. Sistem Pendidikan Nasional. Jakarta: Menkumham. RI.
W.S. Winkel. (1983). Psikologi Pendidikan dan Evaluasi Belajar. Jakarta: Gramedia. Zuhairini dkk: (1983). Methodik Khusus Pendidikan Agama. Surabaya: Usaha Nasional. 